\title{
Research Paper \\ Effectiveness of Parent Management Training (PMT) on Reducing Bullying and Improving Cognitive Emotion Regulation in Students
}

\section{Mansoureh Bahrami ${ }^{1}$, Shahram Vahedi*2, Yousef Adib², Rahim Badri Gargari²}

1. Ph.D. Student of Educational Psychology, Faculty of Psychology and Educational Sciences, University of Tabriz, Iran 2. Professor, Department of Psychology and Educational Sciences, Faculty of Psychology and Educational Sciences, University of Tabriz, Iran

Citation: Bahrami M, Vahedi S, Adib Y, Badri Gargari R. Effectiveness of parent management training (pmt) on reducing bullying and improving cognitive emotion regulation in students. Quarterly Journal of Child Mental Health. 2020; 7(1): 155-167.

\section{http://dx.doi.org/10.29252/jemh.7.1.14}

\section{A R T I C L E I N F O}

Keywords:
Parent Management
Training (PMT),
bullying,
cognitive emotion
regulation,
students

Received: 16 May 2018 Accepted: 7 Aug 2018 Available: 20 Jun 2020

\section{A B S T R A C T}

Background and Purpose: Bullying phenomenon is one of the most common problems of students which may have undesirable and destructive effects on their psychosocial well-being. Alongside, the training system used by the parents may play significant role in preventing the children from learning bullying or engaging in it. Accordingly, the current research was conducted to investigate the effectiveness of parent management training (PMT) on reducing bullying and improving cognitive emotion regulation in students.

Method: This study was a quasi-experimental research with pretest-posttest control group design. The sample included thirty six 10 to 12 - year-old students studying at grades four and five of primary school in Karaj in the academic year 2017-2018, who were selected by cluster sampling and then randomly assigned to either the experimental or the control group ( $\mathrm{n}=18$ per group). Research tools included the children forms of Olweus Bully/Victim Questionnaire (Olweus, 1996) and Cognitive Emotion Regulation Questionnaire (Granefski et al., 2001). Parents of the experimental group received nine 90-min weekly sessions of PMT successively (i.e. one per week), whereas the control group underwent no intervention. Data were analyzed by Multivariable Analysis of Covariance (MANCOVA) through using SPSS Version 20 Software.

Results: Results of data analysis showed that PMT significantly reduced the symptoms of bullying $(\mathrm{F}=120.61, \mathrm{p}<0.001)$ and maladaptive strategies in emotion regulation $(\mathrm{F}=17.98, \mathrm{p}<0.001)$ and improved adaptive strategies $(\mathrm{F}=83.15, \mathrm{p}<0.001)$ in students.

Conclusion: Based on the results of this study, it can be concluded that PMT and change in parenting style and parental behavior patterns play significant roles in preventing the children from learning bullying or engaging in it and can lead to the decrease of bullying behaviors in them.

\footnotetext{
* Corresponding author: Shahram Vahedi, Professor, Professor, Department of Psychology and Educational Sciences, Faculty of Psychology and Educational Sciences, University of Tabriz, Iran.

E-mail addresses: Vahedi117@yahoo.com
} 


\section{تأثير الكوى آموزش مديريت والدين بر كاهش قلدرى و بهبود تنظيم شناختى هيجان دانش آموزان}

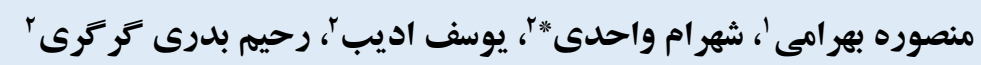

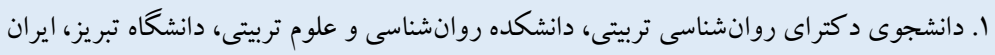

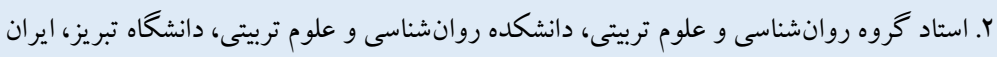

زمينه و هدف: بديده قلدرى يكى از مهم ترين مسائل شايع كود كان امروزى در مدارس است كه بيامدهاى نامطلوب و مخربى بر بهزيستى

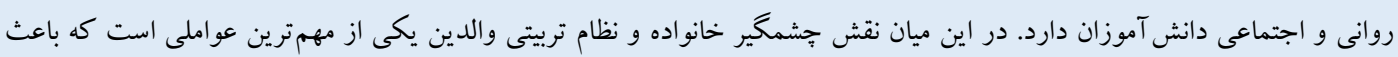

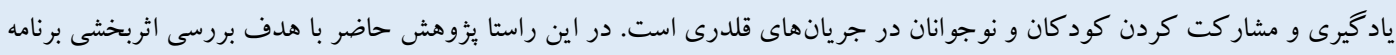

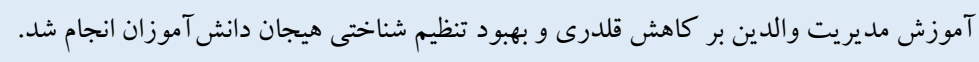

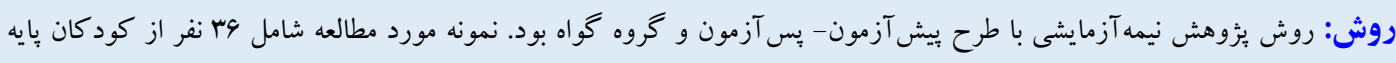

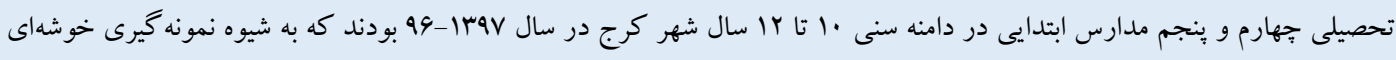

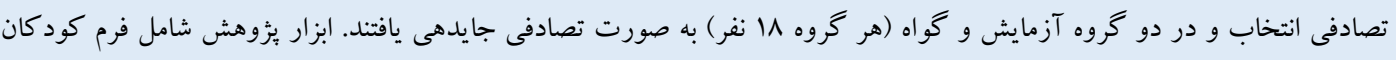

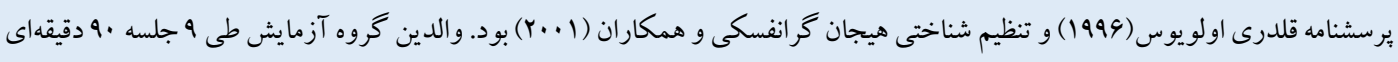

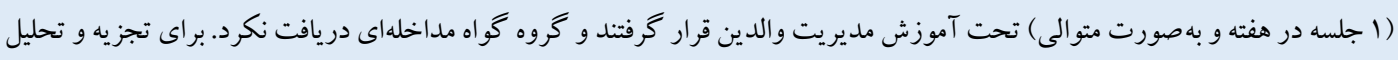

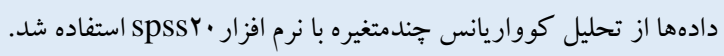

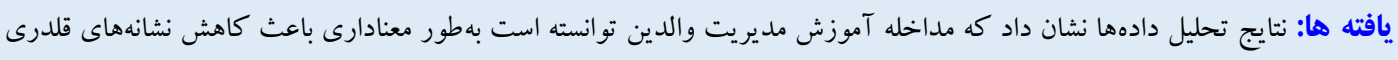

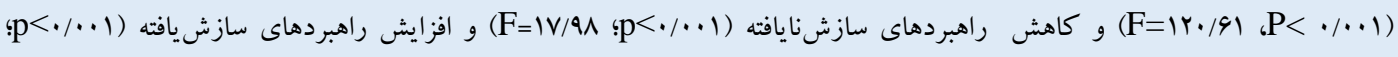
(F=人 $\mathrm{F} / 1 ه$

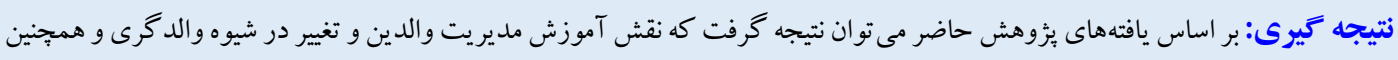

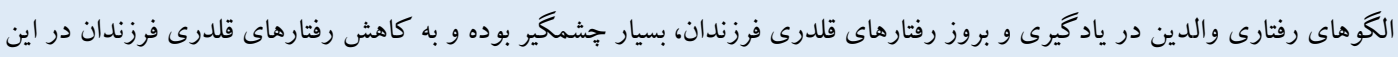




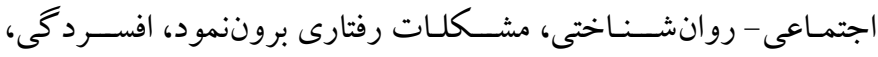

مقلمهه

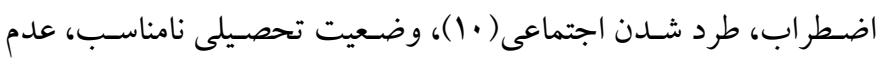

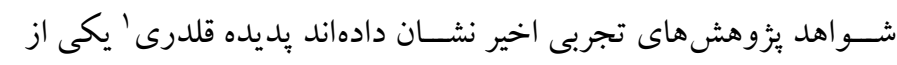

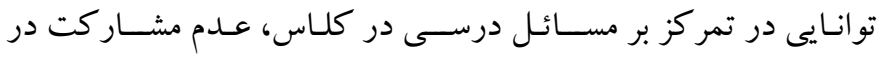

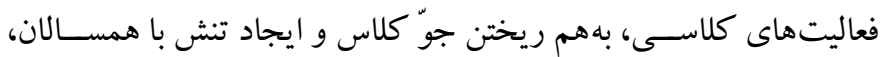

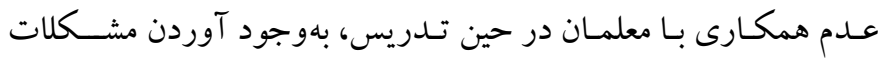
مختلف در سطح مدرسه، فرار و يا اخراج از مدرسه (Iا و r I). بنابراين

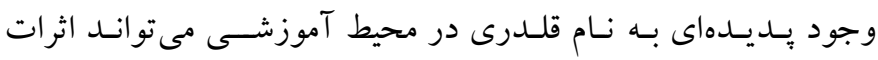

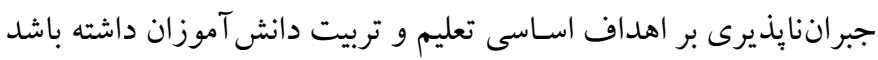

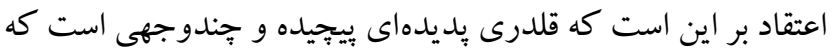
ناشى از ويز گى هاى فردى، ارتباطات خانو ادگىى، روابط با همكلاسى ها،

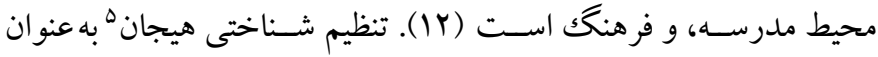

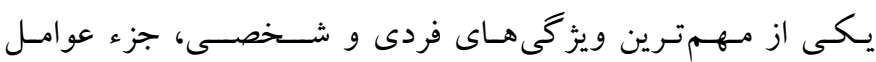

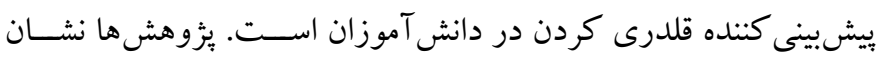

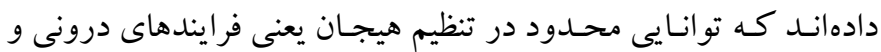
بيرونى مسـئول نظارت، ارزيابى و تغيير واكنش هاى هيجانى، مخصـوصـاً

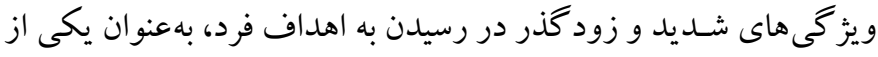

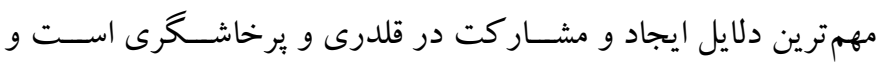

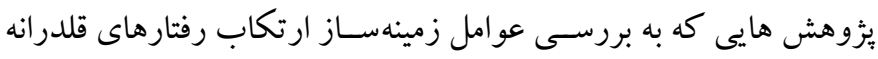

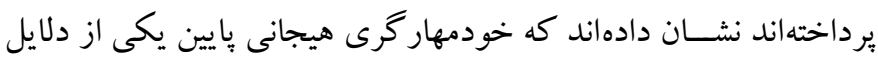

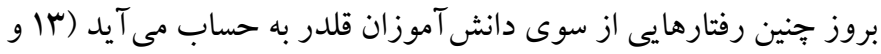

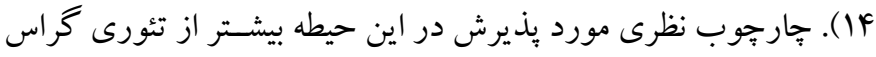

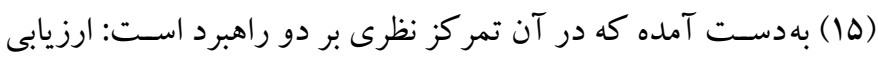
شــــاختى (تلـاش در فكر كردن بـهـ يكك موقعيت و تغيير معنى و اثرات

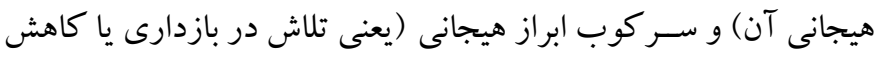
رفتـارهايى با بروز هيجان). ســـح متفاوت تنظيم هيجانى كود كان بيان

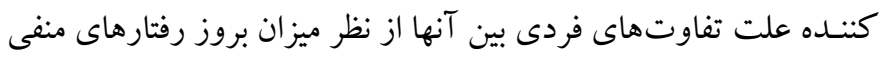

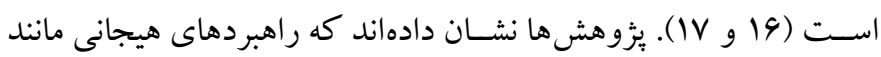
تلافى كردن و انتقامجويى و برونى سـازى كردن مسائل، باعث ادامه يافتن روند قلدرى كردن در آينده و ييامدهاى ضسعيف و ناكار آمد مى شى بـود و

4. Oleos

5. Cognitive emotion regulation

2. Cyber bullying

3. Physical bullying
1. Bullying

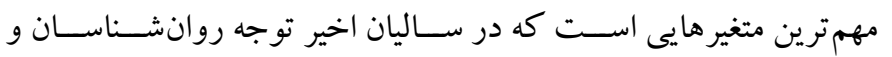
متخصصان تعليم و تربيت را به خود جلب كرده است و يكى از رايجترين مشكلاتى است كه مدارس امروزى با آن مواجه هستند؛ در حالى كه همه دانش آموزان حق برخوردارى از آموزش و تحصـيـل توأم بـا امنيـت را

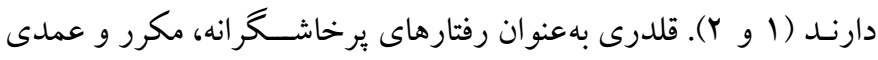

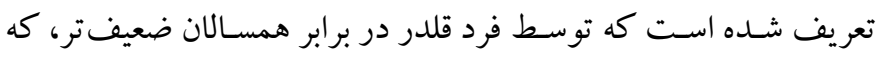

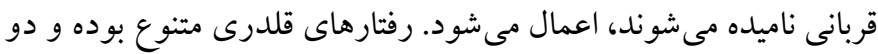

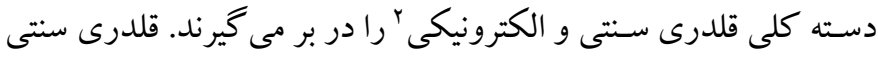

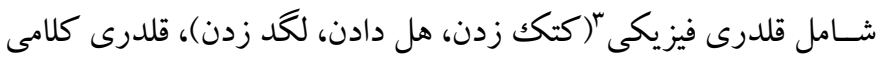
(فحاشسى، تحقير و رنجاندن)، رابطهاى يا عاطفى (محروم سـازى فرد از

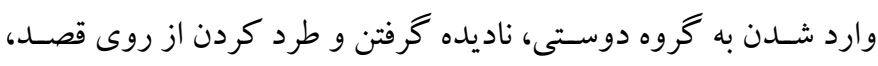

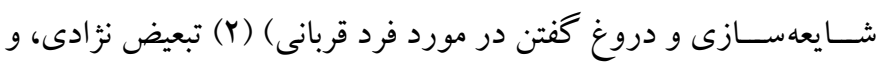
سوءاستفاده جنسى مىشود، ولى قلدرى الكترونيكى شامل كاربرد وسايل

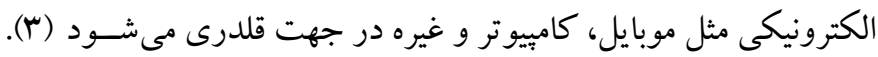

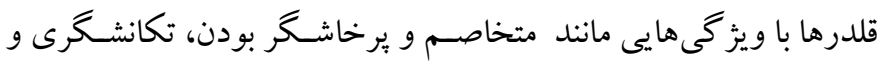

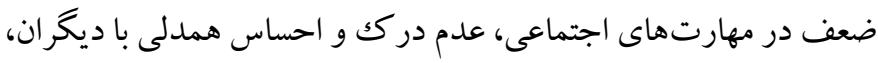

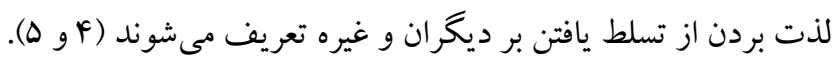
مطالعه در حيطه بديده قلدرى و قربانى شــدن، بهصـورت علمى با

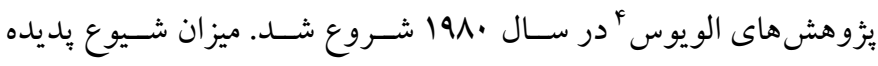

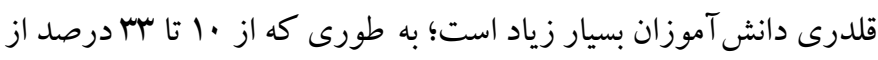

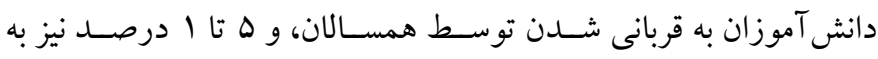

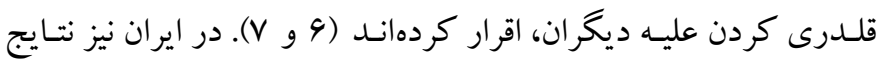
يزّوهش ها نشـان داده اسـت كه •N درصـد دانش آموزان معتقد به وجود

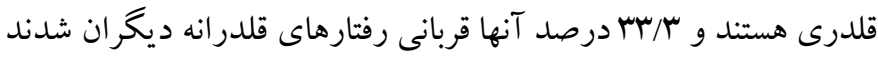

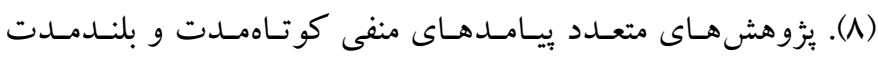
روانشــاختى، اجتماعى، و تحصـيلى قلدرى كردن در دانش آموزان را

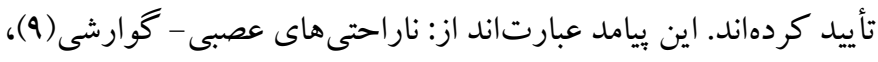

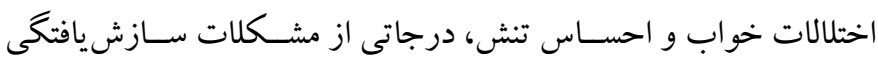


كود كك مىشــود. بنـابر اين كودكانى كـه والـدين خود را طرد كنتسه و

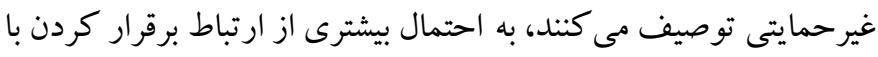

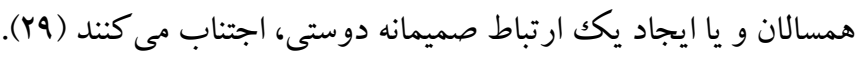

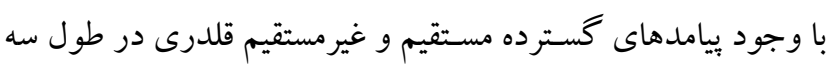

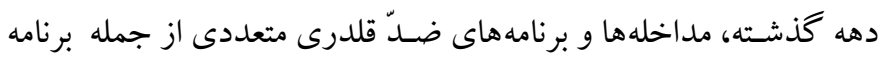

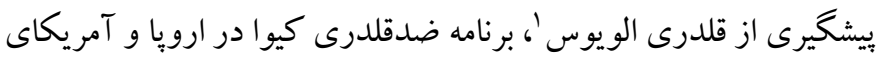

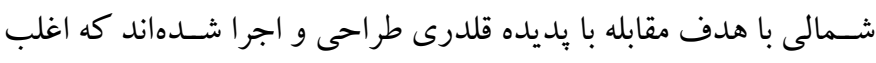

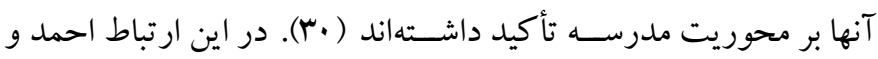

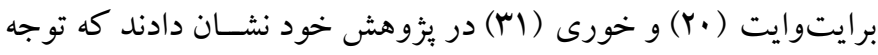
به آموزش تربيت درسـت والدينى به كاهش موارد قلدرى منجر مىشـود.

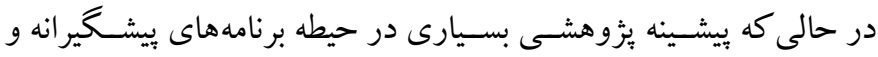

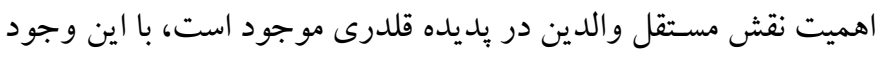

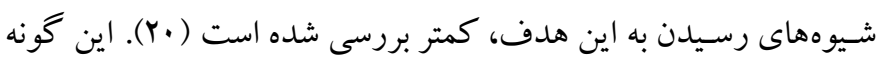

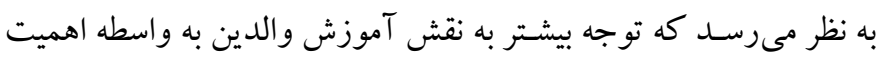

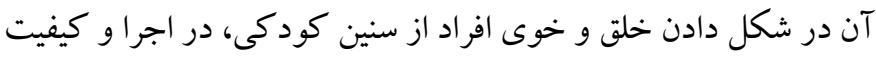

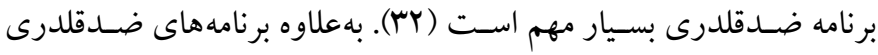
متمركز بر والـدين علـاوه بر كـاهش ميزان قلـدرى مى توانـــد بر ديخر

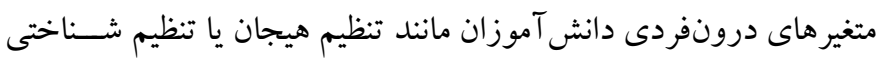

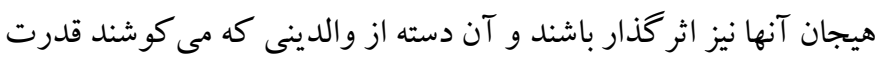

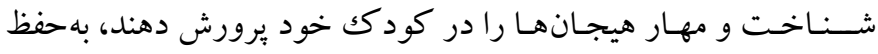

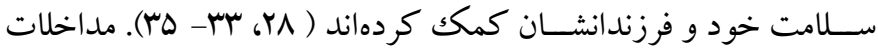
مبتنى بر شــواهـد در حيطه آموزش والدين كود كان با اختلالات رفتارى ترد نشـان مىدهند كه نه تنها اين مداخلات به بهبود رفتارهاى كود كان منجر

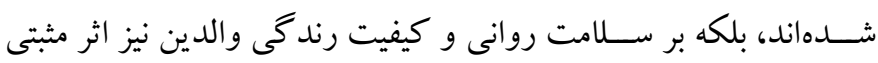
داشـتهاند (4)). لازم به ذكر اسـت كه با وجود اهميت نقش والدين در رفتـارهـاى ارتكاب قلـدرى دانش آموزان، آموزش روشهــاى مديريت

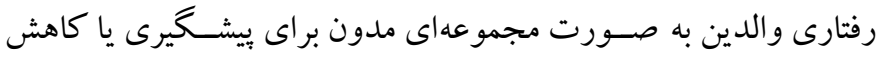

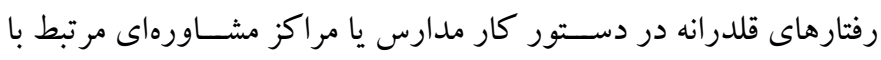

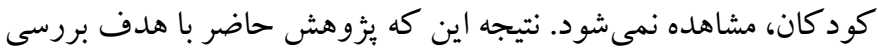

همجِنين رفتار قلدرى مى تواند بهعنوان وسيلهاى براى بايان دادن بهحالات

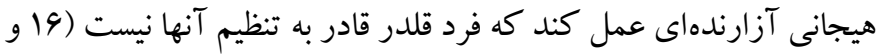

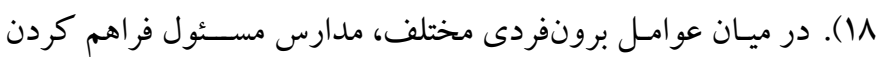

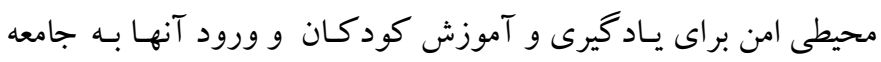

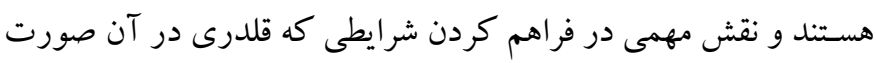

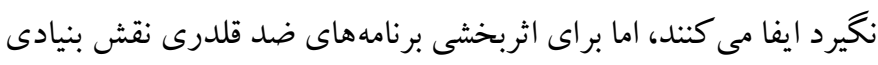

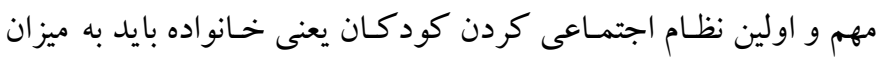

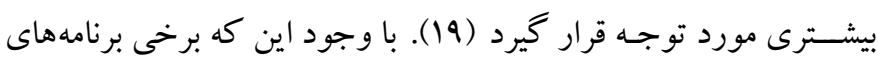

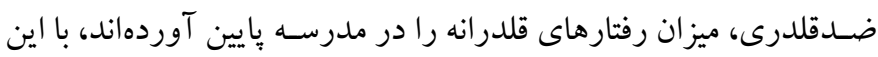
وجود تغييرات بهوجود آمده در اين زمينه در مدارس، كمتر احسـاس و مشـاهده مىشـود و بهنظر مىرسـد از مبناى نظرى بايد بيشتر به نقش نهاد

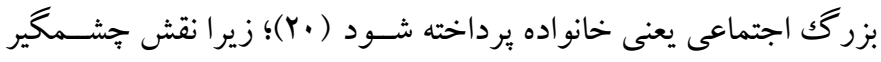

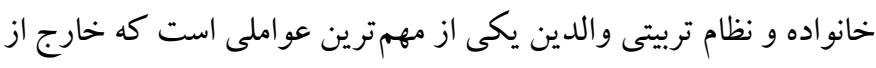

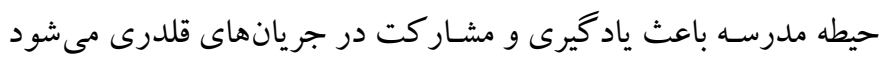

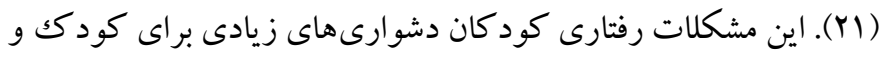

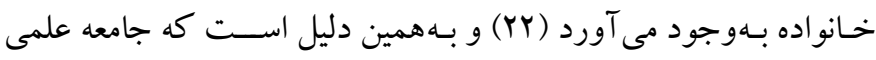

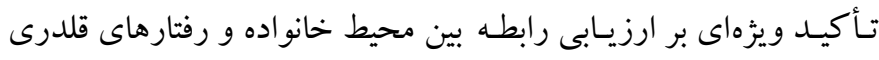

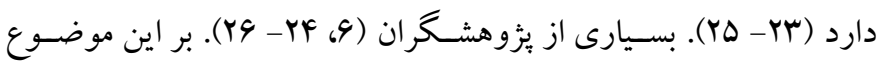

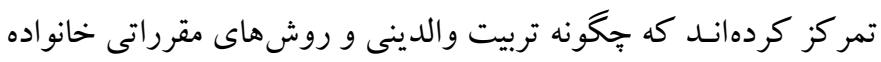
بر ميزان مشاركت كود كان در رفتارهاى قلدرى و قربانى شدن آنها تأثير

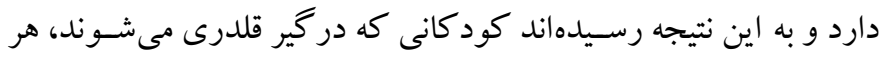

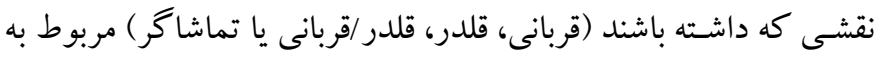

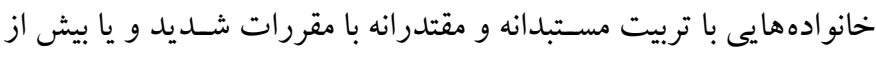

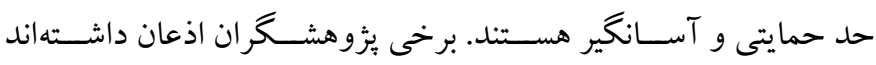

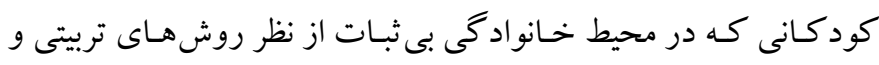
تنبيهى، تحول مى يابند و به جاى روش هاى تشويقى، روش هاى بى رحمانه

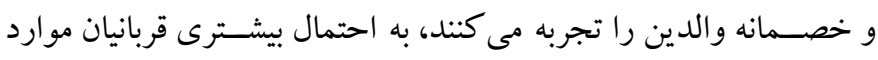

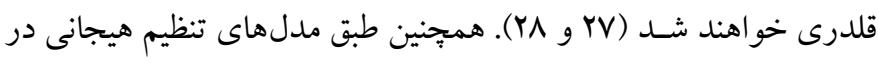

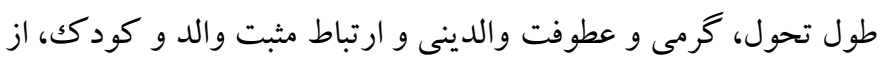

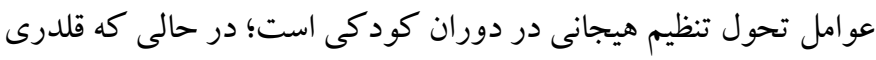

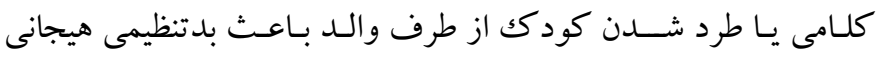


دانش آموزان اسـتفاده شـــ كه شـامل · إخويه براى سـنجش شـكل هاى مختلف قلدرى جسمانى، عاطفى يا اجتماعى، و كلامى استفاده شد. شيوه

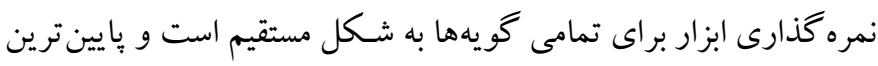

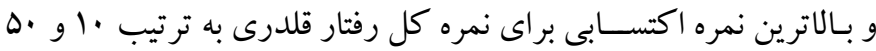

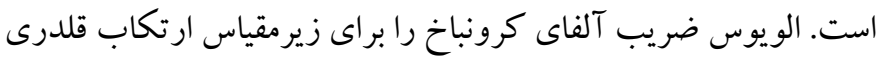

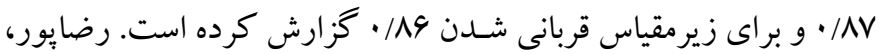
سـورى و خداكريم يُوهشى را با هدف تعيين شـاخصهاى روانسنجى اين ابزار در مـدارس راهنمـايى ايران بر روى نمونسهاى

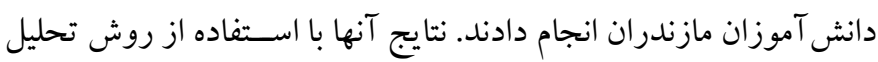
عاملى اكتشـافى نشـان داد كه اين ابزار از روايى مطلوبى برخوردار است.

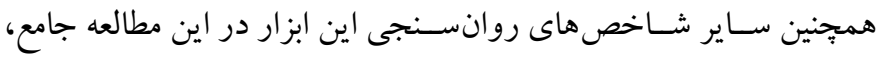

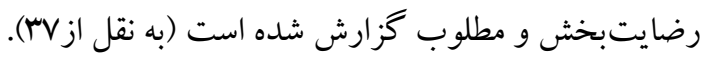

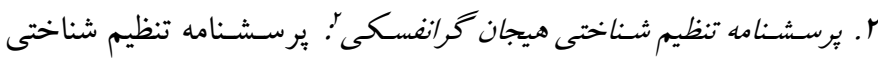

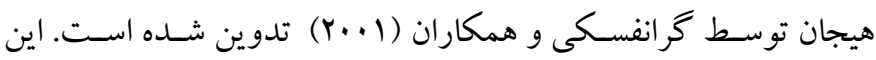

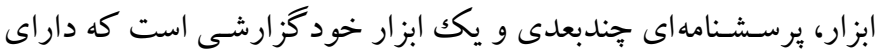

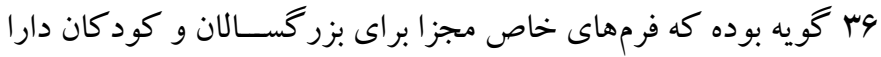

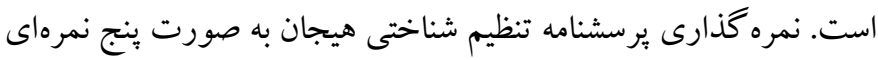

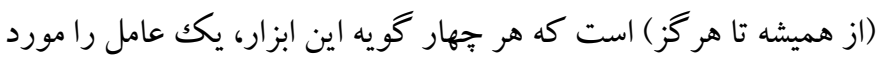

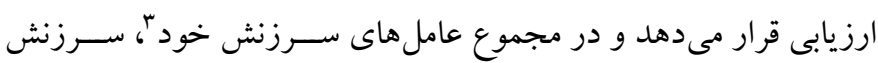

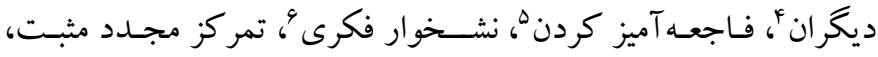

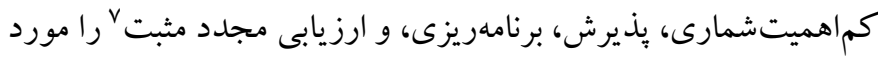

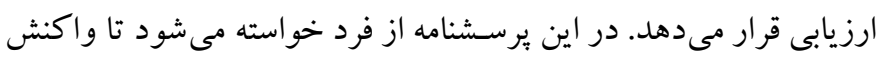

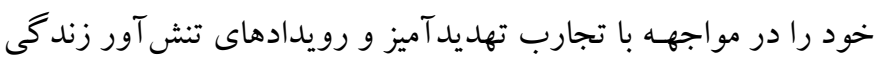

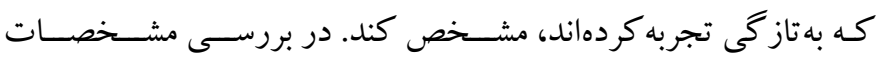

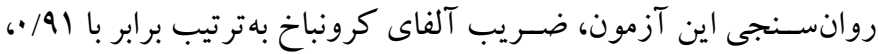

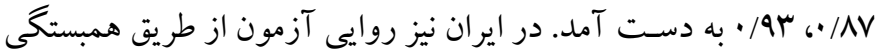

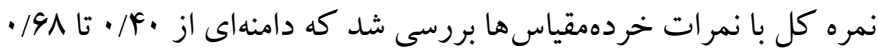

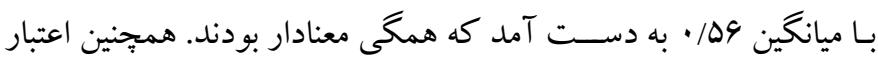
اين يرسشنامه در مطالعه مشهلى، حسنى و ميردورقى با استفاده از ضريب

5. Catastrophizing

6. Rumination

7. Positive reappraisal
تـأثير مؤلفـهـهـاى كليـدى برنـامـهـ آموزش مـــيريـت والـــين بر كـاهش رفتارهاى قلدرانه و تنظيم شناختى هيجان دانش آموزان، انجام شد. الف) طرح يزولهش و شر كت كنند كان: يُزوهش حاضر نيمه آزمايشى

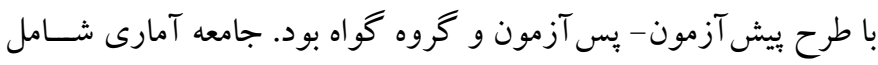

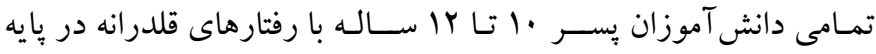
تحصيلى جهارم و بنجم دبستان در سال تحصيلى

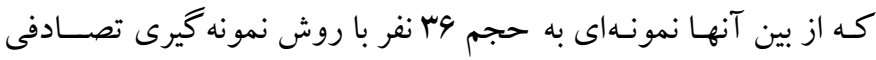

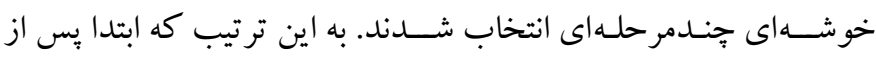

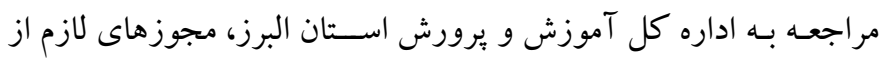

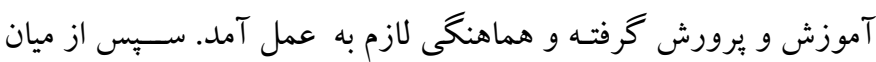
مدارس موجود ب مدرسـه به تصـادف انتخاب شـدند و از هر مدرسـه ب كلاس نيز به تصادف انتخاب شدند و تمامى دانش آموزان اين كلاسها به به

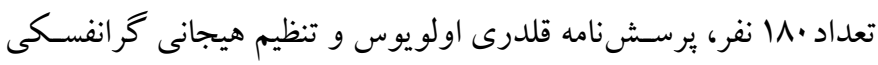

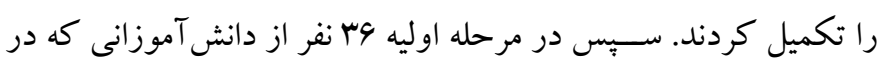

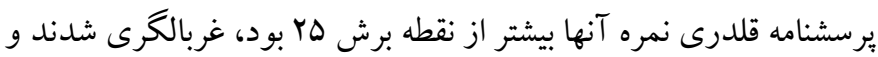
يس از آن يرسشنامه تنظيم هيجانى را تكميل كردند. اين 4َ دانش آموز

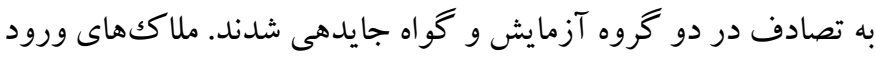

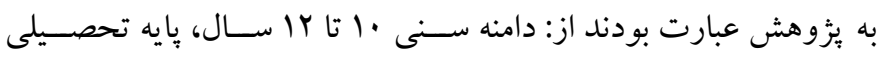

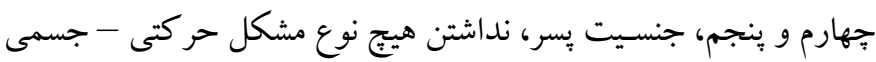

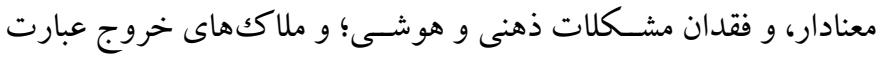

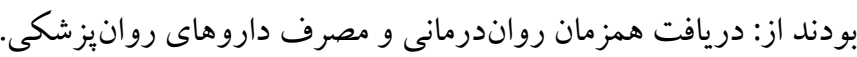
ب) (بزار 1. برسشــامه قللدرى /ولويوس '. اين برسشــامه توسط الويوس در سال

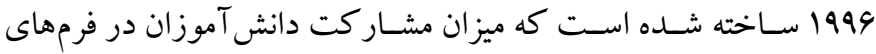

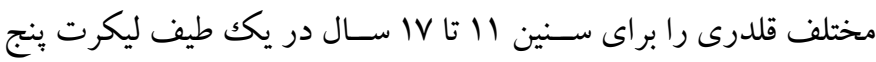
درجهاى به صورت (1=اين اتفاق در جند ماه گذشته برايم نيفتاده است)

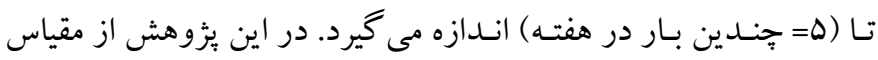
ارتكـاب قلـدرى اين ابزار براى ســنجش ميزان رفتـارهـاى قلــرانـهـ

1. Olweus bullying questionnaire

2. Granovsky Cognitive Emotion Regulation questionnaire

3. Self-blame

4. Blaming others 
شد. اين افراد بِ از مطالعه محتواى جلسات آموزشى نظر خود را درباره

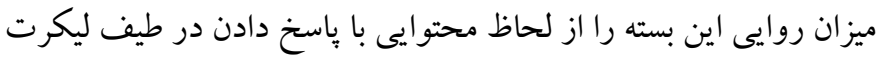

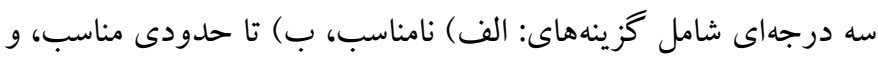
ج) كاملاً مناسب، بيان كردند. ضريب به دست آمده از روايى محتو ايى

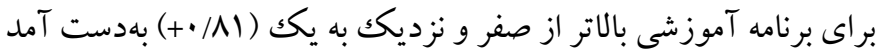
كه نشاندهنده روايى برنامه آموزشى از نظر محتوايى بر اساس نظر داوران

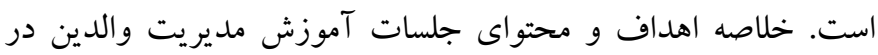
جدول زير گزارش شده است.
آلفاى كرونباخ براى كل مقياسهاى شـناختى AV/ • تز ارش شـده است ( $(\mu, \mu \Delta)$ ج) برنامه مداخلهاى: در اين مطالعه برنامه ضدّ قلدرى آموزش مديريت

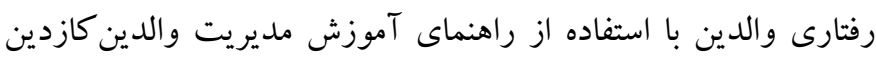

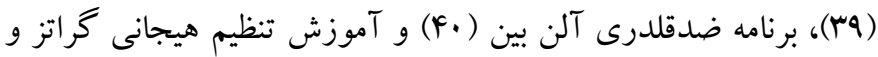
همكاران (F) تدوين شد. براى بررسى روايى اين برنامه از نظرات 9 نفر

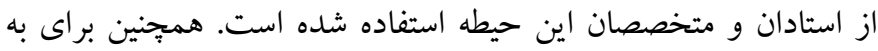
دست آوردن ضريب روايى محتوايى اين برنامه از روش الاشه 'ار استفاده

\section{جدول ا: جارجوب كلى برنامه آموزش مديريت والدين دانش آموزان قلدر}

\begin{tabular}{|c|c|c|}
\hline محتواى هر جلسه & هدف & جلسات \\
\hline 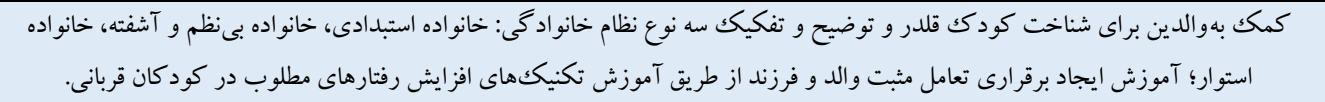 & 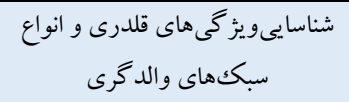 & يكم \\
\hline مرور مطالب جلسه قبل و ارائه بازخورد به تكليف خانكى والدين، ادامه آموزش برقرارى تعامل مثبت، ارائه منطق تكنيككهاى تعاملى، و ارائه & 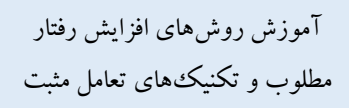 & 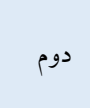 \\
\hline مرور مطالب جلسه قبل و ارائه بازخورد بهتكليف خانه والدين، آموزش قو انين دستور دادن و اطاعت كردن كود كان، ارائه منطق تكنيكهاى & $\begin{array}{l}\text { آموزش تكنيك هاى دستور دادن و اطاعت از خواست والدين }\end{array}$ & سوم \\
\hline مرور مطالب جلسه قبل و ارائه بازخورد به تكليف خانه والدين، آموزش روشهاى كاهش رفتارهاى نامطلوب در كود كان، ارائه تكليف. & $\begin{array}{l}\text { ناموزش تكنيكهاى كاهش رفتار } \\
\text { نامطلوب }\end{array}$ & جهارم \\
\hline 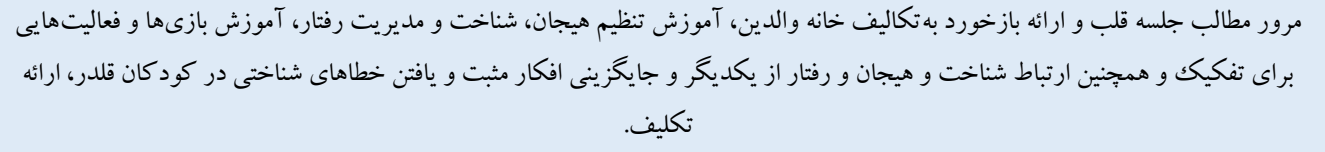 & مديريت رفتارهاى مر تبط با هيجان و شناخت و & شنجم و \\
\hline مرور مطالب جلسه قبل و ارائه بازخورد به تكليف خانه والدين، آموزش شناخت و ابراز هيجانها و احساسات و ار ائه تكنيكها مربوط، ارائه & $\begin{array}{l}\text { آموزش تفكيك شناخت و هيجان و } \\
\text { رفتار از يكديخر }\end{array}$ & هفتم \\
\hline مرور مطالب جلسه قبل و ارائه بازخورد به تكليف خانه والدين، آموزش تكنيكهاى آرميدگى براى مهار هيجانها و احساسات، ارائه تكليف. & 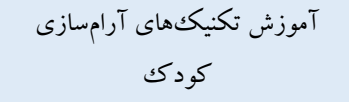 & هشتم \\
\hline 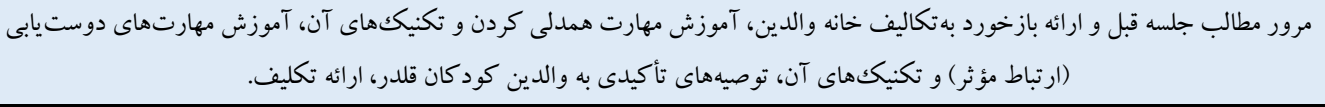 & روابط اجت موز مهارت همدلى براى تقويت دوستى كودكى & نهم \\
\hline
\end{tabular}

در آن توسـط مدير صـادر شــهه بود، حضسور يابند. در مرحله بعد براى

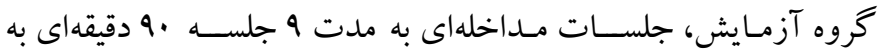
صورت ا جلسه در هفته و به شكل گروهى اجرا شد؛ در حالى كه گروه كو اه مداخلهاى دريافت نكرد. در بايان مداخلات انجام شده، بس بـ آزمون

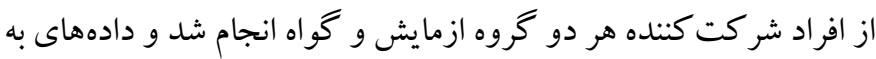

د) روش اجرا: جهـت انتخـاب افراد نمونـه و اجراى اين مطـالعه، ابتــا

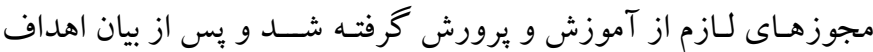
يُزوهش و بـا رعـايـت ملـاحظات اخلاقى مانند محرمانه ماندن اطلاعات و

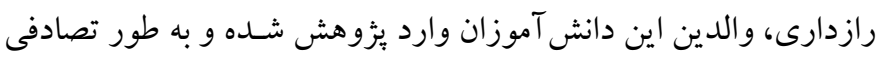

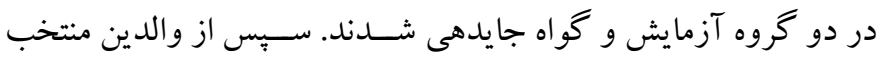
خو استه شد كه در يكى از كلاسهاى مدرسه كه اجازه بر كز ارى جلسات 
ميانگين و انحر اف اسـتاندارد نمرات بِيش آزمون-ِّ آزمون قلدرى دو

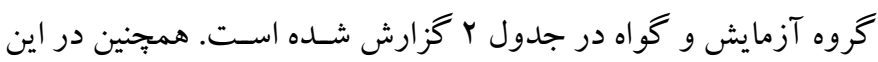

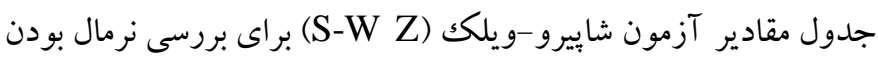

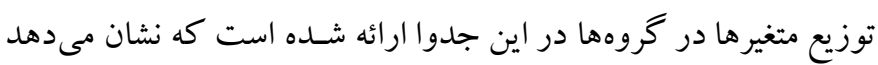

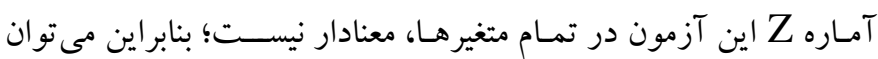
نتيجه گرفت كه توزيع اين متغيرها نرمال است.
دست آمده با روش تحليل كوواريانس يكراهه مورد وارسى و تجزيه و

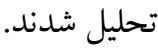

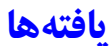
جهت بررسى فرضسيه نخسـت اين مطالعه يعنى "آموزش برنامه مديريت

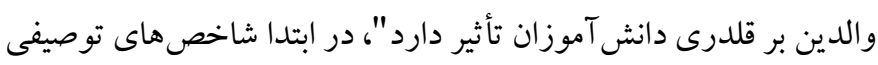

جدول ז: شاخصهاى توصيفى نمرات يِش آزمون-يّ آزمون قلدرى در دو گروه آزمايش و كواه (تعداد: حr)

\begin{tabular}{|c|c|c|c|c|c|c|}
\hline $\mathbf{P}$ & S-W Z & انحراف استاندارد & ميانكين & كروه & وضعيت & متغير \\
\hline$\cdot / \cdot v$ &.$/ 91$ & T/VQ & $1 . / 1 V$ & آزمايش & \multirow{2}{*}{ ي بيش آزمون } & \multirow{4}{*}{ قلدرى كلامى } \\
\hline .19 & $\cdot / 99$ & $1 / 91$ & $9 / \% 9$ & كواه & & \\
\hline$\cdot / \pi r$ & $\cdot / 94$ & $1 /$ V9 & $\Delta / 91$ & آزمايش & \multirow{2}{*}{ پس آزمون } & \\
\hline .191 &.$/ 94$ & $1 / 9 V$ & $9 / \pi$ & كواه & & \\
\hline$\cdot / 11$ &.$/ 94$ & $1 / \mathrm{VA}$ & $9 / 9 \mathrm{~V}$ & آزمايش & \multirow{2}{*}{ ييش آزمون } & \multirow{4}{*}{ قلدرى رابطه اى } \\
\hline .119 & . & $1 / 1 F$ & $9 / 9 \mathrm{~V}$ & كواه & & \\
\hline$\cdot / r \mid$ & . /9r & $1 / \mu 1$ & $r / a r$ & آزمايش & \multirow{2}{*}{ يس آزمون } & \\
\hline.$/$ &.$/ 91$ & I/r & $9 / 19$ & كواه & & \\
\hline . &.$/ 94$ & $r / \Delta$. & $1.19 \mathrm{~V}$ & آزمايش & \multirow{2}{*}{ ييش آزمون } & \multirow{4}{*}{ قلدرى جسمانى } \\
\hline.$/ 10$ & $\cdot / 9 r$ & $r / \cdot r$ & $11 / \cdots$ & كواه & & \\
\hline.$/ 11$ & $\cdot / 9 r$ & $1 / Y \Lambda$ & $91 \cdot$. & آزمايش & \multirow{2}{*}{ پِ آزمون } & \\
\hline$\cdot / r \Lambda$ & ./9F & $Y / \cdot \Lambda$ & $11 / V Y$ & كواه & & \\
\hline .1 .9 & $\cdot / 9$. & $1 / 94$ & $9 / 94$ & آزمايش & \multirow{2}{*}{ يِش آزمون } & \multirow{4}{*}{ قلدرى الكترونيكى } \\
\hline$\cdot / r Y$ & •/१ & $1 / \Delta \Lambda$ & V/Ar & كواه & & \\
\hline$\cdot / \cdot v$ & $\cdot / 91$ & $\cdot / 99$ & r/^q & آزمايش & \multirow{2}{*}{ يس آزمون } & \\
\hline 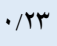 & . $/ 94$ & $1 / \Delta r$ & $V / r \Lambda$ & كواه & & \\
\hline
\end{tabular}

و گواه نيز نشان داد كه ماتريس كواريانس متغيرهاى وابسته در دو گروه

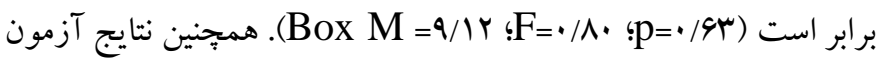
خحى دو بارتلت براى بررسـى كرويت يا معنى دارى رابطه بين مؤلفهاى قلـدرى نشــان داد كه رابطه بين اين مؤلفه ها معنادار اســت (ه • d.f=9 جندمتغيره، نتايج آزمون نشـان داد كه بين دو گروه در مؤلفههاى قلدرى

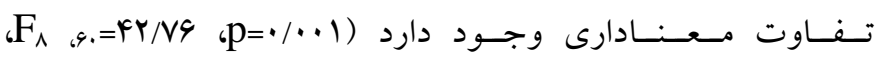

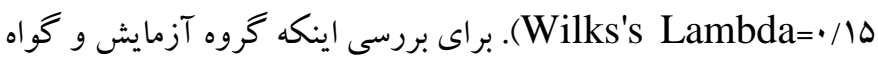
در كدام يكك از مؤلفه هاى قلدرى با يكديگر تفاوت دارند، در جدول س، نتايج تحليل واريانس تككمتغيره گزارش شده است.
براى بررسى تأثير آموزش مديريت والدين بر قلدرى دانش آموزن از تحليل كواريانس جندمتغيره اسـتفاده شـــ. نتايج آزمون بررسـى همكنى شـــب ركرسـيون يِيش آزمون و يس آزمون مؤلفه هاى قلدرى در گروه آزمايش و گواه نشـان داد كه شيب رگرسيون در هر دو گروه برابر است

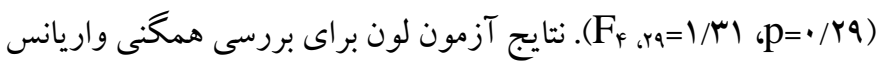
متغيرهاى وابسته در گروهها نيز نشـان داد كه واريانس مؤلفههاى قلدرى

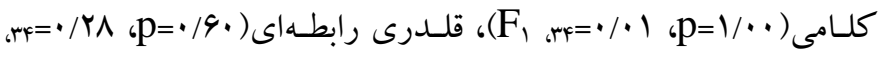
(F)

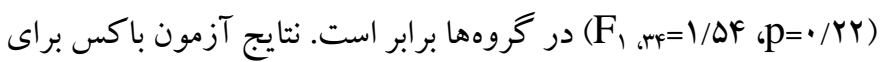
بررسى برابرى ماتريس كواريانس متغيرهاى وابسته در بين گروه آزمايش 
جدول "َ: نتايج تحليل واريانس تككمتغيرى تفاوت كروه آزمايش و تواه در مؤلفههاى قلدرى

\begin{tabular}{|c|c|c|c|c|c|c|c|}
\hline اندازه اثر & $\mathbf{P}$ & $\mathbf{F}$ & خطاى استاندارد & تفاوت ميانكين & ميانكين & & \\
\hline$\cdot / 09$ & $\cdot / \cdot \cdot 1$ & $R Y / \Delta F$ & $\cdot / 09$ & $-r / 94$ & $\begin{array}{l}\Delta / 9 F \\
q / \mu .\end{array}$ & كو آزمايش & قلدرى كلامى \\
\hline.$/ 99$ & $\cdot / \cdot \cdot 1$ & $n r / A r$ & $\cdot / \mu F$ & $-r / A q$ & $\begin{array}{l}r / 9 V \\
9 / 19\end{array}$ & كو آزمايش & قلدرى رابطهاى \\
\hline$\cdot / \mathrm{WV}$ & $\cdot / \cdot \cdot 1$ & $1.9 / 19$ & $\cdot / \Delta F$ & $-8 / 9 \Lambda$ & $\begin{array}{l}91 . r \\
11 / V .\end{array}$ & كو آزمايش & قلدرى جسمانى \\
\hline .194 & $\cdot / \cdot \cdot 1$ & GT/VD & . $/ F r$ & $-r / r V$ & $\begin{array}{l}r / q . \\
V / r V\end{array}$ & كو كمايش & قلدرى الكترونيكى \\
\hline
\end{tabular}

و الكترونيكى مى شـود. همجنين اندازه اثرهاى گزارش شده در جدول r

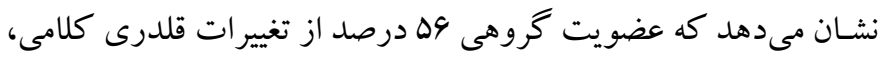

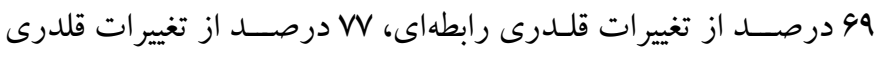
جسمانى، و 99 درصد از تغييرات قلدرى الكترونيكى را تبيين مى كند. براى بررسى فرضيه دوم اين يزوهش يعنى "آموزش برنامه مديريت

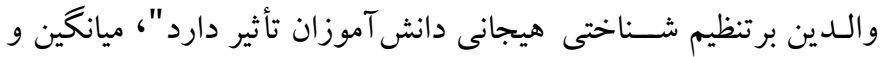

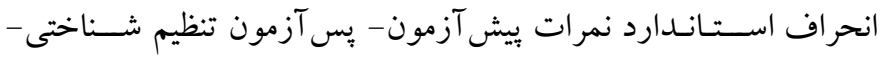

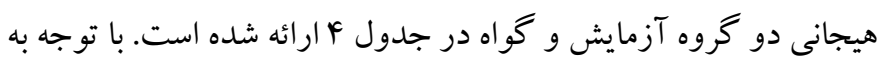

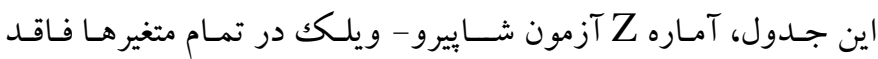
معنادارى آمارى بوده اسـت؛ بنابراين مى توان نتيجه كرفت كه توزيع اين

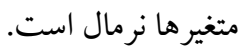

بـا توجه به جدول Y آماره F براى مؤلفههاى قلدرى كلامى (FY/OF)

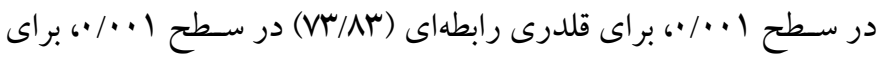

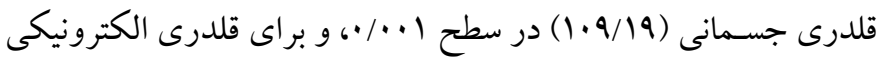

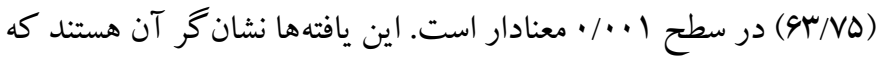

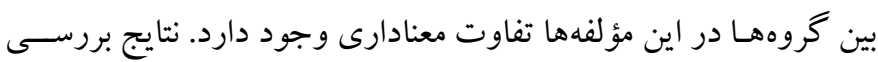

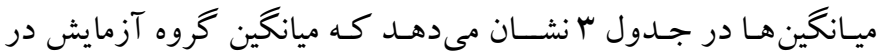

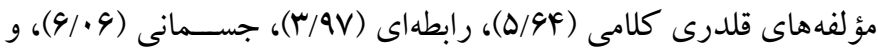

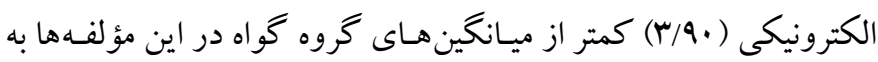

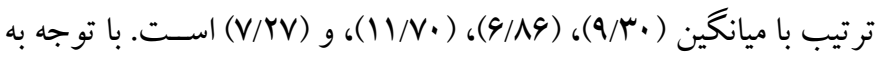
اين يـافتههـا مى توان بيـان داشــت كه آموزش مديريت والدين موجب كاهش قلدرى دانش آموزان در هر جهار بعد كلامى، رابطهاى، جسمانى،

جدول ع: شاخصهاى توصيفى نمرات يِشآزمون-يّى آزمون تنظيم شناختى-هيجانى در دو كروه آزمايش و كواه (تعداد: حس)

\begin{tabular}{|c|c|c|c|c|c|c|}
\hline $\mathbf{P}$ & S-W Z & انحراف استاندارد & ميانَين & كروه & وضعيت & متغير \\
\hline.$/ 19$ &.$/ 94$ & $\Lambda / \cdot V$ & $\Delta Q / Y \wedge$ & آزمايش & \multirow{2}{*}{ ي بيش آزمون } & \multirow{4}{*}{ تنظيم شناختى -هيجانى سازش نايافته } \\
\hline 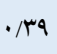 & $\cdot / 90$ & $V / T F$ & $\Delta G / \Delta G$ & كواه & & \\
\hline$\cdot / \cdot v$ &.$/ 91$ & 9/V9 & k9/VA & آزمايش & \multirow{2}{*}{ يس آزمون } & \\
\hline$\cdot / \Lambda$ & . & $\Lambda / r$ & $\Delta 9 / .9$ & كواه & & \\
\hline$\cdot / \Upsilon \wedge$ &.$/ 94$ & $1 \cdot / \Delta \mathrm{V}$ & MN/FF & آزمايش & \multirow{2}{*}{ ي بيش آزمون } & \multirow{4}{*}{ تنظيم شناختى -هيجانى سازش يافته } \\
\hline.$/ 94$ &.$/ 99$ & Q/VQ & Rr/qF & كواه & & \\
\hline .1 .9 &.$/ 91$ & ৭/^. & $9 / / \mathrm{N}$ & آزمايش & \multirow{2}{*}{ يس آزمون } & \\
\hline .194 &.$/ 94$ & $9 / \%$. & FF/VA & كواه & & \\
\hline
\end{tabular}

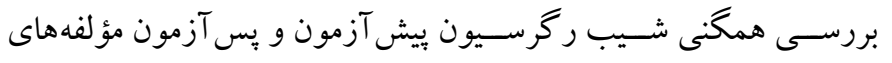

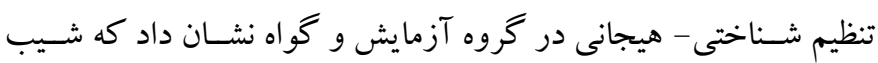

براى بررسى تأثير آموزش مديريت والدين بر تنظيم شناختى -هيجانى دانش آموزن از تحليل كواريانس جندمتغيره اسـتفاده شــــ نتايج آزمون 
هيجـانى نشــان داد كه رابطه بين اين مؤلفهها معنادار اســت (ه •/

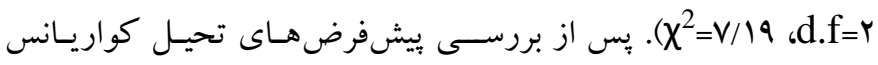
جندمتغيره، نتايج آزمون نشــان داد كه بين دو گروه در مؤلفههاى تنظيم

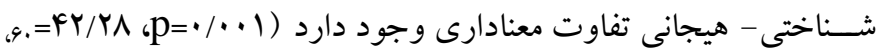
Wilks's Lambda=•/r ، $\mathrm{F}_{\text {^ }}$ كواه در كـدام يـك از مؤلفـههاى تنظيم شــناختى - هيجانى با يكديكر تفـاوت دارنـد، در جـدول ه، نتـايج تحليـل واريانس تككتمتغيره گزارش

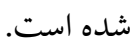

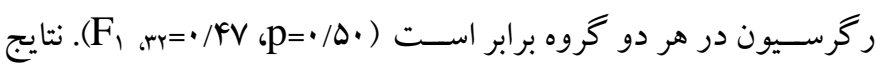
آزمون لون براى بررسـى همخنى واريانس متغيرهاى وابســه در گروهها نشـان داد كه وارياانس مؤلفههاى تنظيم شـناختى - هيجانى سـازشنايافته

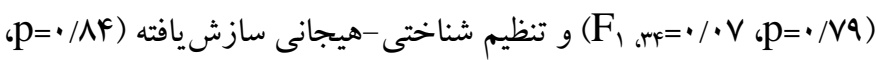

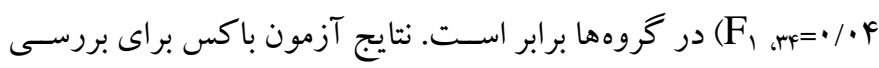
برابرى ماتريس كواريانس متغيرهاى وابسته در بين گرووه آزمايش و گو اه نيز نشـان داد كه ماتريس كواريانس متغيرهاى وابسـته در دو گرووه برابر است (Box M=ه/19 F=1/9 ( بر ایى بررسـى كرويت يا معنادارى رابطه بين مؤلفههاى تنظيم شــناختى -

\begin{tabular}{|c|c|c|c|c|c|c|c|}
\hline اندازه اثر & $\mathbf{P}$ & $\mathbf{F}$ & خطاى استاندارد & تفاوت ميانكين & ميانكين & & \\
\hline \multirow{2}{*}{$\cdot / 4 \Delta$} & \multirow{2}{*}{$\cdot / \cdot 1$} & \multirow{2}{*}{$\mid V / 91$} & \multirow{2}{*}{$r / F \Delta$} & \multirow{2}{*}{$-1 \cdot / 4$} & KG/YY & آزمايش & \multirow{2}{*}{ تنظيم شناختى -هيجانى سازش نايافته } \\
\hline & & & & & $\Delta 9 / 9 Y$ & كواه & \\
\hline \multirow{2}{*}{$\cdot / N$} & \multirow{2}{*}{$\cdot / \cdot 1$} & \multirow{2}{*}{$1 \mathrm{~V} / 10$} & \multirow{2}{*}{ r/A } & \multirow{2}{*}{$r q / 41$} & $99 / 91$ & آزمايش & \multirow{2}{*}{ تنظيم شناختى -هيجانى سازش يافته } \\
\hline & & & & & $F r / \Delta V$ & كواه & \\
\hline
\end{tabular}

\section{بحث و نتيجه كيرى}

هدف از يزوهش حاضــر، بررسـى اثربخشـى الكوى آموزش مديريت والدين بر كاهش قلدرى و بهبود تنظيم شناختى هيجان دانش آموزان بود. نتايج فرضيه نخست نشان داد تفاوت معنادارى بين گروه آزمايش و گو اه در نمرات يس آزمون قلـدرى وجود دارد و الكوى آموزش مـديريست والـدين باعث كاهش مؤلفههاى قلدرى دانش آموزان شـــده اســتـ. اين

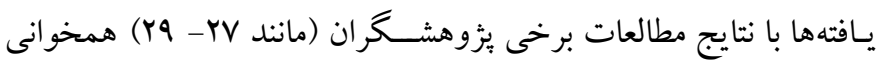
دارد. در تبيين نتـايج اين يزٔوهش مى توان كفـت كه با توجه به مدلهاى نظرى ارائه شـده در حوزه قلدرى، نقش آموزش ملديريت والدين و تغيير در شـــيوه والـدگرى و نيز الكوهـاى رفتارى والدين در يادگيرى و بروز رفتـارهاى قلدرى فرزندان بسـيار جشـــــير بوده و به كاهش رفتارهاى قلدرى فرزندان منجر مى شــود. كود كان رفتار قلدرى كردن را از طريق مشـاهده و تقليد رفتار افراد الكو به ويزٔه كسانى كه روابط نزديكك با آنها دارند، ياد مى گيرند؛ جون افر اد الكو، رفتارهاى خشونت آميز راقبول و يا تقويت مى كنند. اگر رفتارهاى والدين به خصـوص در اوايل كودكى بر روش هاى سـختخير انه و تنبيهى و خصـوصـاً تنبيه هاى بلنى، مبتنى باشــ، مى تواند عامل مهمى در تقويت رفتارهاى قلدرانه فرزندان شـود. بسيارى
با توجه به جدول ها آماره F بر اي مؤلفههاى تنظيم شـناختى -هيجانى سـازشنايافته (IV/AN) در سـطح I I + • • و براى تنظيم شـناختى -هيجانى

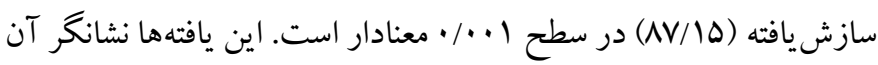
هستند كه بين كروهها در اين مؤلفهها تفاوت معنادارى وجود دارد. نتايج بررسـى ميـانكينهـا نيز در جـدول ه نشــان مىدهـد كه ميانكين كروه آزمايش در مؤلفههاى تنظيم شــناختى -هيجانى ســازشنايافته (F/YY)

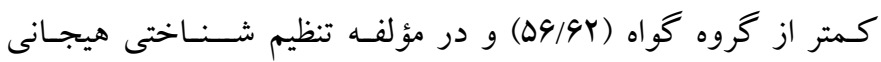

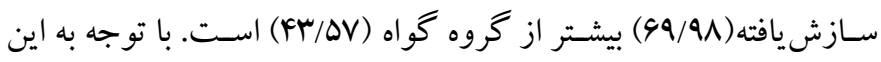
يافتها مى توان بيان داشــت كه آموزش مديريت والدين موجب كاهش تنظيم شــاختى -هيجانى سـازش نايافته و افزايش تنظيم شـناختى هيجانى سـازش يافته دانش آموزان مى شـود. همجينين اندازه اثرهاى كزارش شـده در جدول ه نشـان مىدهد كه عضسويت گرووهى، ها درصسد از تغييرات

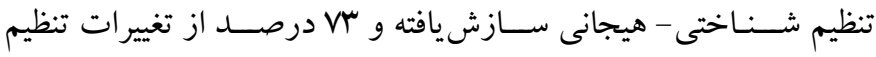
شناختى -هيجانى سازشنايافته را تبيين مى كند. 


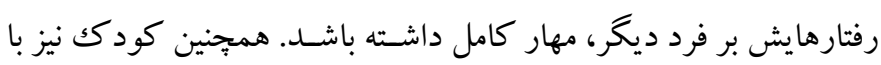

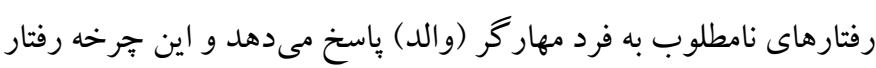

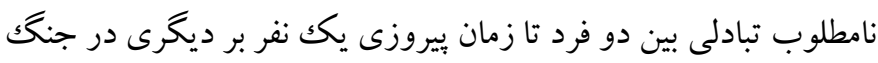

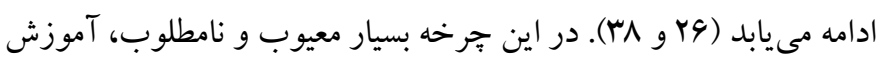

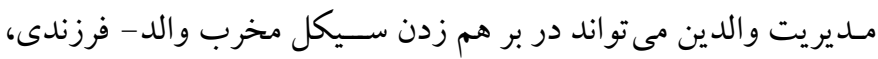

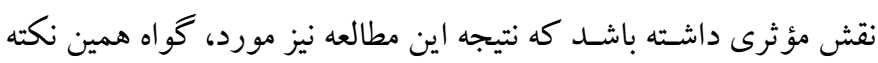
بوده است. در تأييد يافتهاى مربوط به فرضيه دوم اين بزوهش يعنى تأثير مثبت

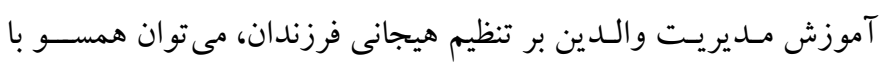

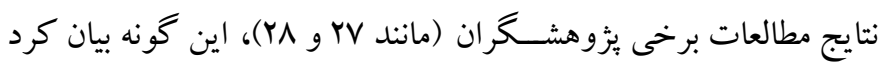

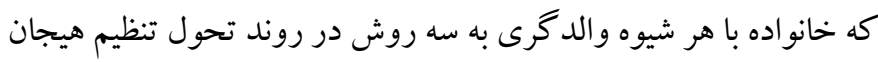

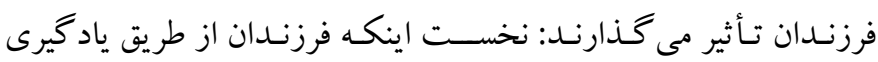

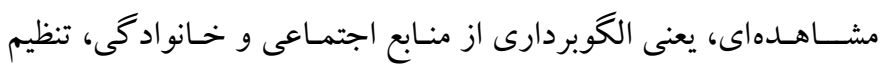

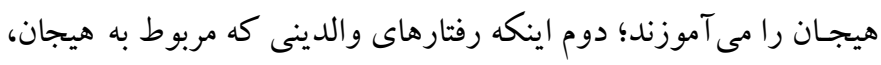
تربيت هيجانى، و مديريت هيجانى اسـت، تحول تنظيم هيجانى كود كان

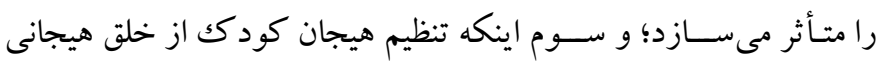

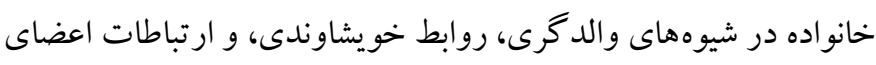

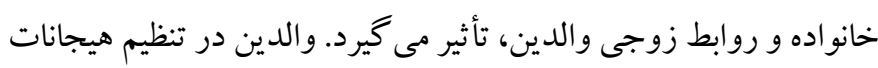

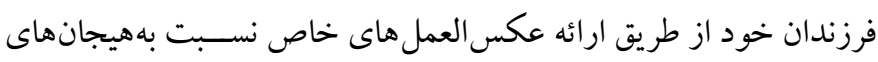

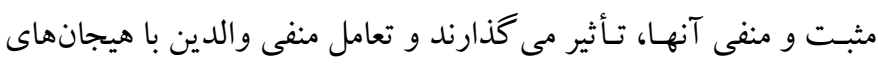
فرزندان به عملكرد ضعيف اجتماعى و مشكلات تنظيم هيجان آنها منجر

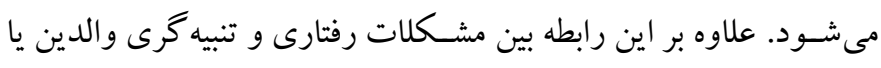

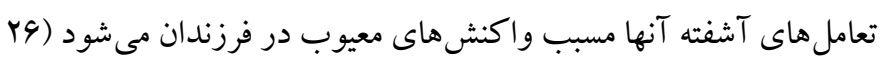

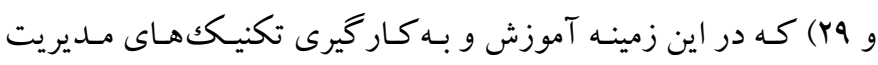

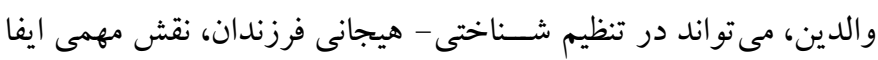

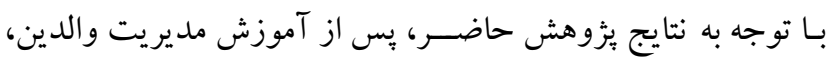

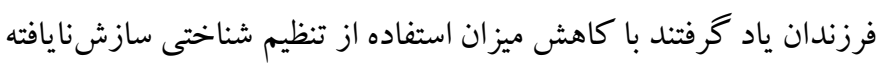
هيجان، ميزان مشـكلات هيجانى خود را كاهش دهند و در نهايت تنظيم

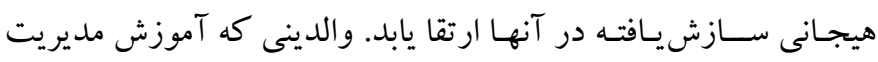

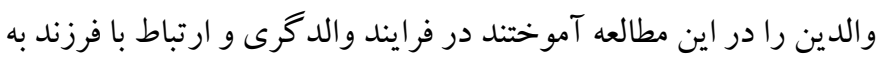

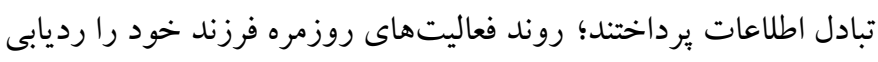

از يززوهشگران در حيطه ياد گيرى نيز معتقدند كه خشونت و برخاشگرى

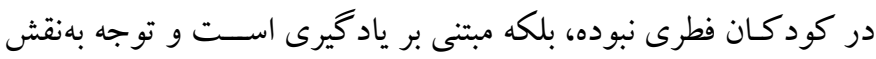

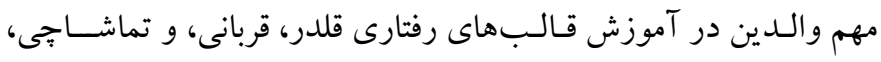

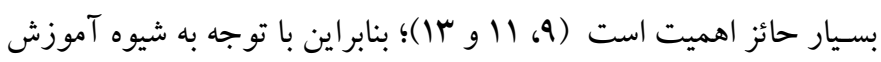

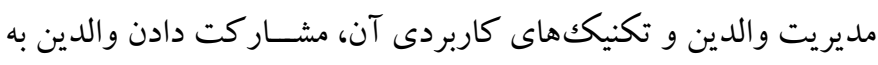
عنوان ركن اساسى بديده قلدرى و بيامدهاى مربوط به آن باعث مى شود

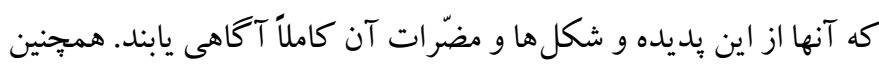

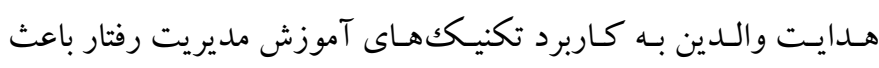

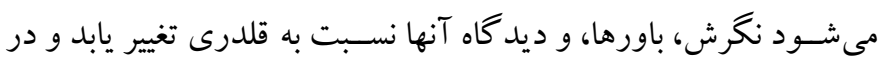

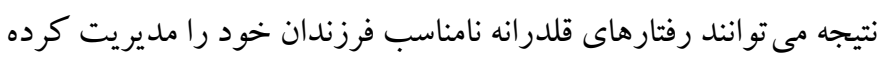

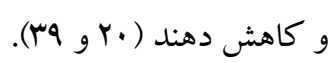

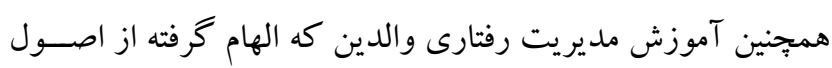

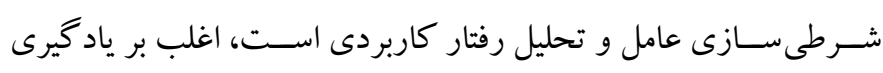

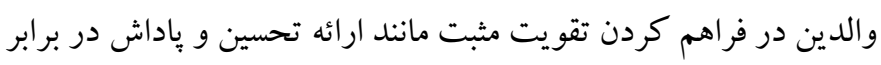

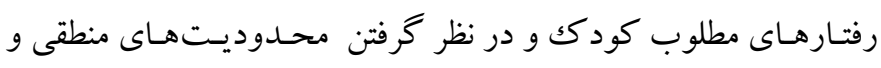

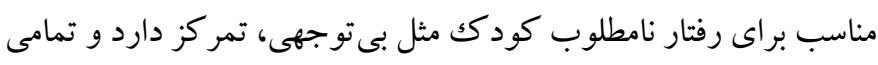

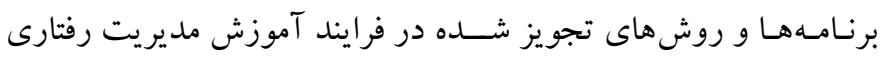

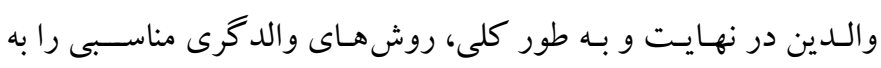

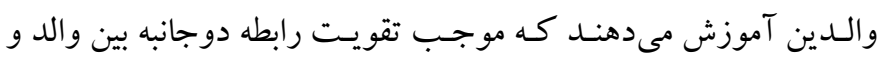

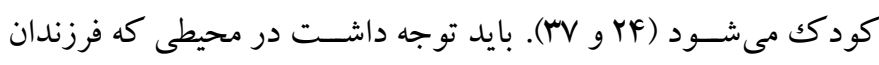

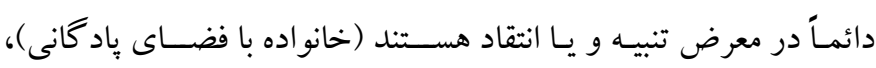

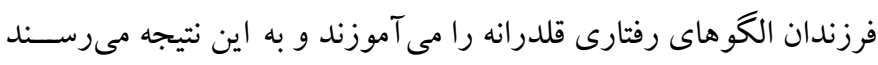

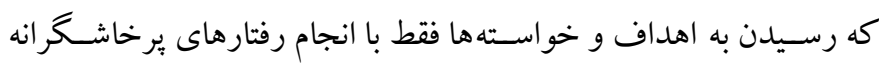

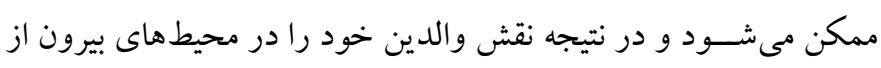
خانه به صورت مستقيم با نمايش رفتارهاى قلدرى و يا بهطور غيرمستقيم

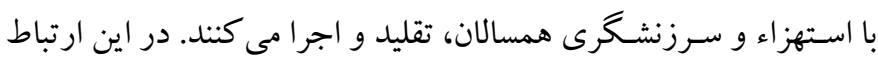

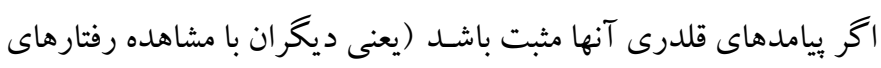

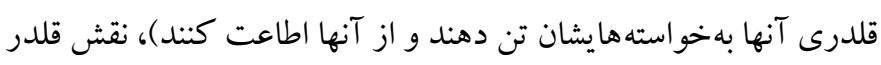

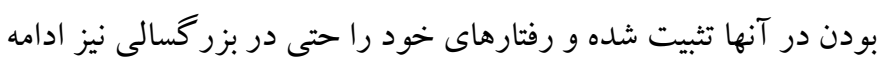

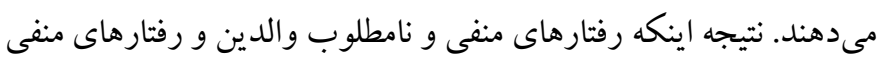

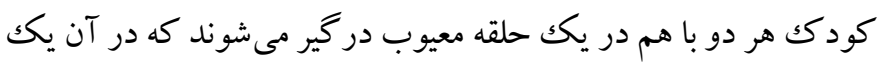

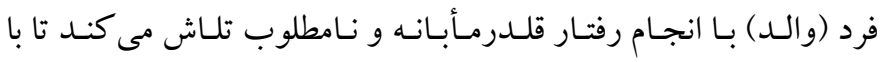


توجـه قرار گيرد تـا اين راهبردهـا بـهمملكردهاى خود كار شــناختى در نوجوانى تبديل شوند.

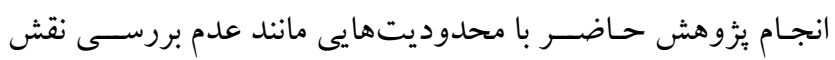

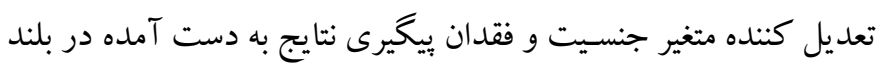

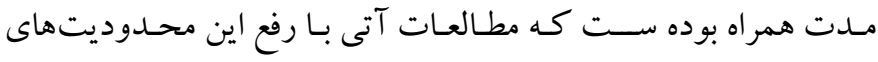

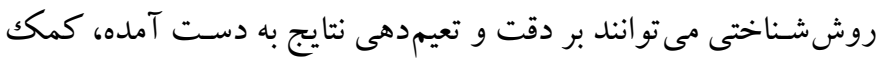

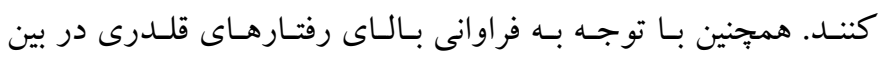

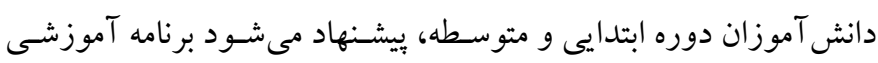

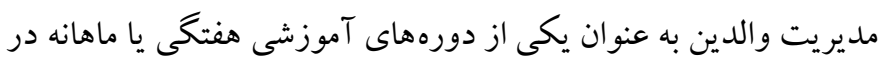
مدارس ايران به طور منظم براى والدين دانش آموزان اجرا شود. تشـكر و قدردانى: اين يزوهش بر كرفته از ياياننامه دكتراى خانم منصــوره

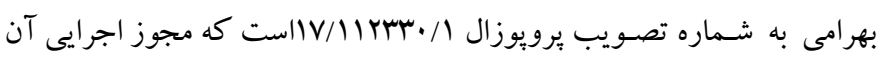

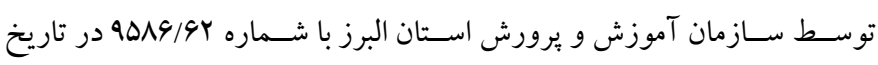

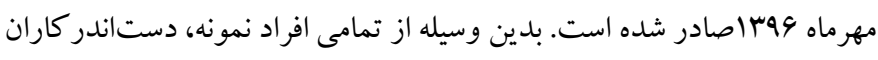

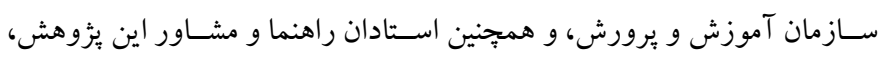
تشكر و قدردانى مىشود.

تضاد منافع: اين بُزوهش هيج گونه تعارض براى نويسند كان به دنبال نداشته است.
مى كردند؛ در ارتباط با مسائل فرزند در خارج از محيط منزل، روى آورد

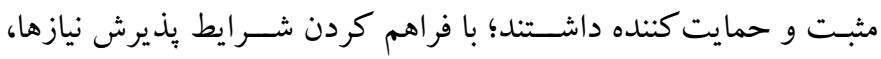

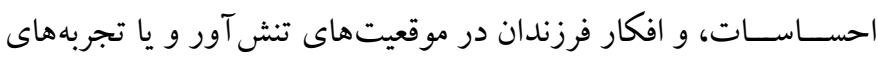
سـتق، زمينه را براى استفاده از راهبردهاى شـناختى سـازش يافته تنظيم

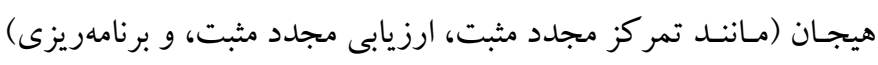

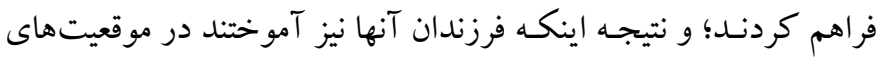

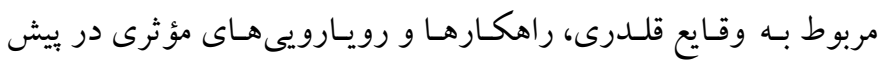

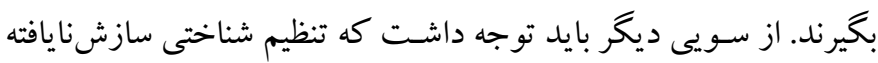

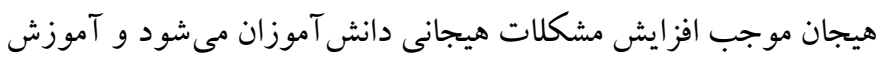
مديريت والدين مى تواند به عنوان نقش واســطهاى در كمكك به مفرزندان در توسعه راهبردهاى سـازش يافته براى تنظيم شناختى هيجان عمل كند.

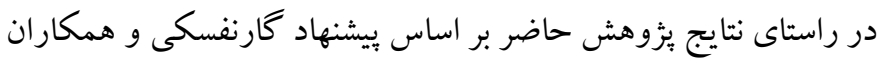

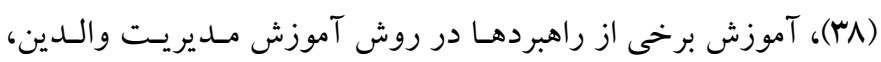

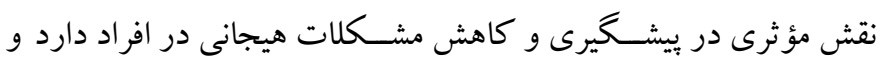

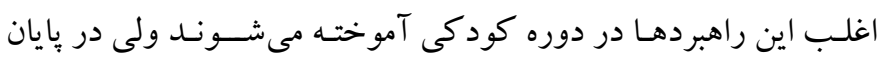

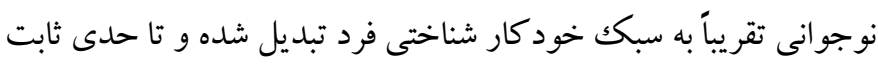

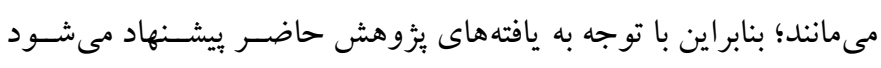

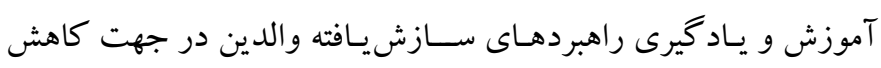

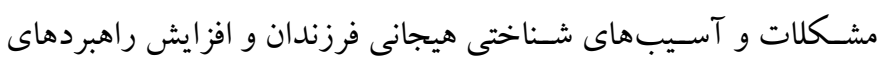

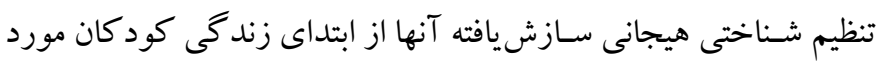




\section{References}

1. Cheraghi A, Piskin M. A comparison of peer bullying among high school students in Iran and Turkey. Procedia Soc Behav Sci. 2011; 15: 2510-2520. [Link]

2. Wang J, Iannotti RJ, Luk JW. Patterns of adolescent bullying behaviors: Physical, verbal, exclusion, rumor \& cyber. J Sch Psychol. 2012; 50(4): 521-534. [Link]

3. Camacho S, Hassanein K, Head M. Cyberbullying impacts on victims' satisfaction with information and communication technologies: The role of perceived cyberbullying severity. Inf Manage. 2018; 55(4): 494507. [Link]

4. Felipe MT, García S de O, Babarro JM, Arias RM. Social characteristics in bullying typology: Digging deeper into description of bully-victim. Procedia Soc Behav Sci. 2011; 29: 869-878. [Link]

5. Kwak M, Oh I. Comparison of psychological and social characteristics among traditional, cyber, combined bullies, and non-involved. Sch Psychol Int. 2017; 38(6): 608-627. [Link]

6. Hymel S, Swearer SM. Four decades of research on school bullying: An Introduction. Am Psychol. 2015; 70(4): 293-299. [Link]

7. Hartley MT, Bauman S, Nixon CL, Davis S. Comparative study of bullying victimization among students in general and special education. Except Child. 2015; 81(2): 176-193. [Link]

8. Mazaheri Tehrani MA, Shiri S, Valipour M. Studying nature and prevalence of bullying in zanjan's rural secondary schools. Educational Psychology. 2015; 11(36): 17-38. [Persian]. [Link]

9. Gini G, Pozzoli T. Association between bullying and psychosomatic problems: A meta-analysis. Pediatrics. 2009; 123(3): 1059-1065. [Link]

10.Kowalski RM, Limber SP. Psychological, physical, and academic correlates of cyberbullying and traditional bullying. J Adolesc Health. 2013; 53(1, Supplement): S13-S20. [Link]

11.Olweus D, Limber SP. Bullying in school: evaluation and dissemination of the olweus bullying prevention program. Am J Orthopsychiatry. 2010; 80(1): 124134. [Link]

12. Swearer SS, Doll B. Bullying in schools: An ecological framework. J Emot Abuse. 2001; 2(2-3):723. [Link]

13.Terranova AM, Morris AS, Boxer P. Fear reactivity and effortful control in overt and relational bullying: A six-month longitudinal study. Aggress Behav. 2008; 34(1): 104-115. [Link]
14.Kokkinos CM, Voulgaridou I. Relational and cyber aggression among adolescents: Personality and emotion regulation as moderators. Comput Human Behav. 2017; 68: 528-537. [Link]

15. Gross JJ. The emerging field of emotion regulation: An integrative review. Rev Gen Psychol. 1998; 2(3): 271-299. [Link]

16.Gross JJ. Antecedent-and response-focused emotion regulation: Divergent con-sequences for experience, expression, and physiology. J Pers Soc Psychol. 1998; 74(1): 224-237. [Link]

17.Gardner SE, Betts LR, Stiller J, Coates J. The role of emotion regulation for coping with school- based peer- victimization in late childhood. Pers Individ Dif. 2017; 107: 108-113. [Link]

18.John OP, Gross JJ. Healthy and unhealthy emotion regulation: Personality processes, individual differences, and life span development. J Pers. 2004; 72(6): 1301-1334. [Link]

19. Bevilacqua L, Shackleton N, Hale D, Allen E, Bond L, Christie D, et al. The role of family and school-level factors in bullying and cyberbullying: A crosssectional study. BMC Pediatr. 2017; 17: 160. [Link]

20. Ahmed E, Braithwaite V. Bullying and victimization: Cause for concern for both families and schools. Soc Psychol Educ. 2004; 7(1): 35-54. [Link]

21.Politi E. School bullying: The phenomenon, the prevention and the intervention. Procedia Soc Behav Sci. 2014; 152: 268-271. [Link]

22. Kheiry H, Salehi I, Soltani Shal R. The effectiveness of stress management training on marital satisfaction and parental stress in mothers with children with behavioral problems. Quarterly Journal of Child Mental Health. 2018; 4(4): 3-13. [Persian]. [Link]

23. Gardner FL, Moore ZE. Understanding clinical anger and violence: The anger avoidance model. Behav Modif. 2008; 32(6): 897-912. [Link]

24. Waseem M, Ryan M, Foster CB, Peterson J. Assessment and management of bullied children in the emergency department. Pediatr Emerg Care. 2013; 29(3): 389-398. [Link]

25. Wolke D, Tippett N, Dantchev S. Bullying in the family: Sibling bullying. Lancet Psychiatry. 2015; 2(10): 917-929. [Link]

26. Norlizah CH, Ee SH. Relationship between Bully's behaviour and parenting styles amongst elementaryschool students. International Journal of Education and Training. 2015; 1(1): 1-12. [Link]

27.Papanikolaou M, Chatzikosma T, Kleio K. Bullying at school: The role of family. Procedia Soc Behav Sci. 2011; 29: 433-442. [Link] 
28. Morris AS, Silk JS, Steinberg L, Myers SS, Robinson LR. The role of the family context in the development of emotion regulation. Soc Dev. 2007; 16(2): 361388. [Link]

29.Aka BT, Gencoz T. Perceived parenting styles, emotion recognition and regulation in relation to psychological well-being. Procedia Soc Behav Sci. 2014; 159: 529-533. [Link]

30.Thompson F, Smith PK. Anti-bullying strategies in schools: What is done and what works. $\mathrm{Br} \mathrm{J}$ Educ Psychol. 2012; 2(9): 1-21. [Link]

31. Khoury L. Bullying prevention and intervention: realistic strategies for schools. J LGBT Youth. 2014; 11(2): 176-181. [Link]

32.Jiménez-Barbero JA, Ruiz-Hernández JA, LlorZaragoza L, Pérez-García $M$, Llor-Esteban B. Effectiveness of anti-bullying school programs: A meta-analysis. Child Youth Serv Rev. 2016; 61: 165175. [Link]

33.Zahediyan S, Kafi Masule SM, Khosrov Javid M, Fallahi M. Efficacy of emotion regulation training on coping strategies among female elementary school students. Quarterly Journal of Child Mental Health. 2015; 2(1): 9-19. [Persian]. [Link]

34. Howitt D, Cramer D. Introduction to statistics in psychology. Edición: 5. Harlow, England: Prentice Hall; 2011, pp: 109-117. [Link]

35.Mashhadi A, Hasani J, Mirdoraghi F. Factor structure, reliability and validity of Persian version of the cognitive emotion regulation questionnaire-children form (CERQ-K-P). Journal of Fundamentals of Mental Health. 2012; 14(55): 246-259. [Persian]. [Link]
36. Frisch C, Tirosh E, Rosenblum S. Parental occupation executive training (POET): An efficient innovative intervention for young children with attention deficit hyperactive disorder. Phys Occup Ther Pediatr. 2020; 40(1): 47-61. [Link]

37.Rezapour M, Soori H, Khodakarim S. Testing psychometric properties of the perpetration of bullying and victimization scales with olweus bullying questionnaire in middle schools. Journal of Safety Promotion and Injury Prevention. 2013; 1(4): 212221. [Persian]. [Link]

38.Garnefski N, Kraaij V. Relationship between cognitive emotion regulation strategies and Depressive symptoms: A comparative study of five specific samples. Pers Individ Dif. 2006; 40(8): 16591669. [Link]

39.Kazdin AE. Problem-solving skills training and parent management training for oppositiona defiant disorder and conduct disorder. In: Weisz JR, Kazdin AE, editor. Evidence-based psychotherapies for children and adolescents. 2nd ed. New York, NY, US: The Guilford Press; 2010, pp: 211-226. [Link]

40.Beane AL. Protect your child from bullying: expert advice to help you recognize, prevent, and stop bullying before your child gets hurt. Edición: 1. San Francisco, CA: Jossey-Bass; 2008, pp: 73-126. [Link] 41.Gratz KL, Rosenthal MZ, Tull MT, Lejuez CW, Gunderson JG. An experimental investigation of emotion dysregulation in borderline personality disorder. J Abnorm Psychol. 2006; 115(4): 850-855. [Link] 